\title{
Teaching the Three E's of Sustainability through Service-Learning in a Professional Program
}

\author{
Tony G. Reames ${ }^{1}$, Jeannette M. Blackmar ${ }^{2}$, and John C. Pierce ${ }^{3}$
}

${ }^{1}$ Tony G. Reames is an assistant professor at the University of Michigan School for Environment and Sustainability and director of the Urban Energy Justice Lab.

${ }^{2}$ Jeannette M. Blackmar is executive director of the Baldwin City, Kansas Chamber of Commerce.

${ }^{3}$ John C. Pierce is an affiliate faculty at the University of Kansas School of Public Affairs and Administration and Oregon State University School of Public Policy, and professor emeritus and vice chancellor emeritus at University of Colorado at Colorado Springs.

Using seven established course design principles for effective service-learning, this chapter discusses the lessons learned in teaching the three E's of sustainability: environmental; economic; and (social) equity, in a professional program at an American Midwestern public university.

The "service-learning portion of this class was immensely constructive to both my psyche and knowledge of what it means to be an instrument of public service," reflected one student in their course journal at the end of spring semester in the Sustainability and Civic Engagement course taught in a public administration program at an American Midwestern public university. In professional, or applied, education "it is insufficient to learn for the sake of knowledge and understanding alone; one learns in order to engage in practice" (Martin 2010, 1). In the era of major climate change concern, there is little question of the urgency for trained professionals in public administration and other applied fields such as architecture, urban planning, business and engineering, to not only be familiar with, but to possess real-world experience with and sensitivity to the issue of sustainability, identified by some as "the issue of the age" (Reid 2008, 16). Servicelearning, a booming enterprise in contemporary higher education over the last four decades, has a clear and powerful, normative rationale based in a civic mission connected to democratic ideology and communitarian public concerns (Sigmon 1979; Boyte and Holander 1999; Staton et al. 1999;

This is the author manuscript accepted for publication and has undergone full peer review but has not been through the copyediting, typesetting, pagination and proofreading process, which may lead to differences between this version and the Version of Record. Please cite this article as doi: $\underline{10.1002 / \mathrm{tl} .20374 .}$

This article is protected by copyright. All rights reserved. 
Ostrander 2004). Linking education to addressing social problems and balancing cognitive, psychomotor and affective domains, service-learning is the most felicitous mechanism for delivering comprehensive sustainability professional education (Jones et al. 2010; Sipos et al. 2008).

Service-learning is used to characterize a wide range of experiential learning activities. Furco $(1996,10)$ identified at least five types of service programs along a continuum based on intended purpose and focus: volunteerism; community service; field education; service-learning; and internships. Service-learning is located in the middle of this continuum and is unique in its "intention to equally benefit the provider and the recipient of the service as well as to ensure equal focus on both the service being provided and the learning that is occurring" (Furco 1996, 5). The most distinctive feature of service-learning is "having civic education be a deliberate educational goal through which students develop an understanding of their current and future role in their communities" (Bringle et al. 2004, 6) and receive academic credit for the learning that occurs as a result of the service experience (Howard 1993).

One of the future roles for students in their communities could be as a sustainability professional. Over the last decade, the number of local governments and corporations with sustainability officers or coordinators has increased several folds (Pierce et al. 2013; Dyllick and Hockerts 2002). Sustainability is the subject of a growing scholarly enterprise focused on its understanding in varying local contexts (Portney 2003; Budd et al. 2008; Saha 2009). Sustainability also refers to other values, including the long-term persistence of the distribution of equitable social and economic resources, not only across segments of a population, but also across time and across generations (Fiorino 2010). Sustainability is comprehensive, analytical, normative and flexible; attributes which offer promise for orienting and guiding professional fields and education (Fiorino 2010). 
The widely used conceptualization of sustainability is generally organized into three " $\mathrm{E}$ " domains: environmental; economic; and (social) equity (Opp and Sanders 2013). However, communities and corporations have implemented sustainability in piecemeal approaches often focusing primarily on environmental and economic sustainability, while woefully neglecting social equity aspects of the concept (Portney 2003; Saha 2009; Fiorino 2010). Further, there is a dearth of critical research examining pedagogical practices beneficial for teaching that ensures achievement of core competencies in all three E's of sustainability across professional higher education curricula. While several case studies examine teaching sustainability through service-learning, social equity is often largely invisible, resembling what is seen in practice, focusing primarily on environmental or economic sustainability (Keen and Baldwin 2004; And and Sheaffer 2006) or teaching models for courses or universities primarily based on ecological principles (Burns 2011; Brundiers et al. 2010; Moore 2005). Thus, guaranteeing that service-learning projects in our Sustainability and Civic Engagement course incorporated each of the environmental, economic, and (social) equity dimensions of sustainability was essential to the design and execution of the course.

In this chapter we contribute to sustainability education by exploring two research questions. First, is service-learning an appropriate vehicle for delivering sustainability education in a professional program? Second, how do course design and execution contribute to students acquiring core competencies in sustainability education? We present lessons learned in our Sustainability and Civic Engagement course based on assessments of the course viewed from the perspectives of the instructors, students, and service-learning project partners.

\section{Procedures}

\section{The Course}

According to Imperial, Perry, \& Katula (2007) there are seven critical design principles for successfully incorporating service-learning into professional higher education programs: (1) explicit 
connections between the service activity and the learning objectives; (2) reflection; (3) appropriate time commitment or amount of contact; (4) student input; (5) faculty commitment; (6) perceptible impact of the service activity; and (7) feedback loops, which provided the framework for designing, executing, and assessing the successes and challenges experienced during this course.

The sixteen-week Sustainability and Civic Engagement course was divided into three sections: two 7-week sections and one 2-week section. The first 7-week section involved in-class activities such as background readings, lectures, and discussions on the meaning of sustainability and issues relating to sustainable communities. The second 7-week section involved an intensive focus on service-learning group projects with activities occurring primarily outside of the classroom. In the third section, the final two weeks of the course, students returned to the classroom to finalize and present the results of their service-learning group projects. The service-learning project was a major component of the course, representing $40 \%$ of students' grade. Students participated in one of two group-based, sustainability-related projects. During the service-learning section of the course students visited their project sites, met with project partners, and conducted primary and secondary research.

We established relationships with two service-learning partner organizations. A full-time staff member from each organization served as project liaison. Interestingly, the projects were quite different and located about 30 miles apart, providing a unique opportunity to simultaneously explore the three E's of sustainability and execute service-learning within the context of two distinct project scenarios: an urban nonprofit; and a rural county government.

The urban service-learning project was in collaboration with an organization's whose mission is to attract, coordinate and provide resources to assist in transforming neighborhoods into healthy, sustainable communities in partnership with its residents. The service-learning project involved identifying a series of sustainability dimensions and indicators for their five "Sustainable 
Communities" goals: (1) developing, preserving, investing in the physical environment; (2) increasing family income and wealth; (3) stimulating economic activity, locally and regionally; (4) improving access to quality education; and (5) fostering livable, safe and healthy environments. Students collected baseline data for indicator benchmarking in order to track neighborhood change resulting from the organization's planned interventions.

The rural service-learning project was in collaboration with a county's recently established food policy council. The food policy council was formulating a series of policy goals to recommend to the county commission regarding the preservation of agricultural land, means to facilitate the economic development of local food production and distribution, and vehicles for creating institutional (e.g., schools, corrections) policies for purchasing locally produced food. Students identified instruments and mechanisms currently in use in communities around the nation to attain similar policy goals, creating policy summary sheets describing the effectiveness of existing policies and identifying of individuals who could serve as resources for the food policy council.

\section{Sample}

The students $(N=14)$ represented all academic levels, comprised of ten upper-level undergraduate students, and four graduate students. There were five data sources used to evaluate this course across the two research questions and seven course design principles: 1) A baseline knowledge survey; 2) weekly student journals reflecting on reading assignments, lectures, and service-learning project engagement; 3) instructor observations; 4) service-learning partner reactions; and 5) responses to an anonymous, university-administered end of term course evaluation.

\section{Analytic technique}

This qualitative research case study involved using the seven course design principles to code students' open-ended survey responses and weekly journals, instructor notes, and community This article is protected by copyright. All rights reserved. 
partner follow-up, and conducting descriptive statistics on data from the end of term course evaluation. In the next section we present results to our two research questions using the seven course design principles to identify lessons-learned about how a professional program course execution infused with real-world opportunities contributed to students acquiring core competencies in sustainability.

\section{Results}

\section{Research Question 1}

Our first research question exploring whether service-learning is an appropriate vehicle for delivering sustainability education in a professional program was assessed across five course design principles: reflection; student input; feedback loops; appropriate time commitment or amount of contact; and faculty commitment.

\section{Reflection}

Having a built-in mechanism for student reflection across the entire semester, by requiring students to maintain a weekly journal, offered a unique opportunity to track student progress and perceptions for this analysis. However, the quality of the journal entries varied widely, from terse summaries of readings and activities, to more expansive interpretations, to extended critical commentary about the entire service-learning process. Group reflections were also encouraged, but not required, during service-learning project meetings and in formal class sessions. We recognized that quality of the reflection experience should be improved. Several purposeful efforts to improve quality could include: incorporating an early lecture on journaling methods might have improved quality and clarified expectations; using journaling as a start-up or ending activity in class to allow real-time reflections, such as, infusing opportunities for journal sharing in small groups to foster accountability and deeper reflections; and using technology such as online portals to streamline the journaling process. Known as e-journaling, this supports synergistic dialogue between instructor and This article is protected by copyright. All rights reserved. 
students and overcomes logistical issues of writing, submitting and reviewing traditional paper journaling (King and LaRocco 2006).

\section{Feedback loops}

We expressed to our service-learning partners that it was imperative they be forthcoming about their expectations of students and about the fluidity of their organizational environments within which the projects were occurring. Several students commented that the fluid nature of expectations and their partner organizations provided them a real-world glimpse into the environments they may work in one day, while others compared and contrasted this experience with their current work environments.

We determined that with multiple projects, it was beneficial to periodically have groups present progress reports to the entire class, to maintain course cohesiveness, transfer knowledge, and discuss challenges, triumphs, and diversity in how sustainability issues arose in various contexts. We found that students from different groups consulted with one another about challenges they faced.

It was also important to devise a mechanism for obtaining information about the relative contribution of individual students to the service-learning project success, such as, 360-degree peer evaluations where students provided feedback on each other at various points during the project, not just at the end.

\section{Student input}

There was considerable opportunity for student input throughout the course, albeit within significant limits. Students were given a choice between the two service-learning opportunities. Within each project group, students themselves assigned responsibilities and tasks. Students worked out the timing of the project development and the nature of their presentation. At the same time, 
the format and content for the final project was bounded by the needs and expectations of both the service-learning partner and instructors as well as the students evolving understanding of the concept of sustainability.

\section{Appropriate time commitment or amount of contact}

The service-learning component of the course required significant time commitment from engaged students. A number of the students express that the time commitment was inappropriate, particularly as the class was predominantly comprised of full-time working students, and students with significant personal or family responsibilities. This is sometimes more common in professional, or applied, educational programs than in liberal arts programs, thus the flexibility of individual students in the course to accomplish service-learning tasks varied considerably. Not only were they asked to gather data and prepare materials for a final report to their service-learning partners, they also were expected to be involved in off-site activities outside of class, often at a considerable distance from their residences or the university. For instance, one student commented, "it was very difficult to coordinate the requirements of this class with work." Another student commented that "it should initially be made clear to students how much time outside of the scheduled class period service-learning requires." Other students commented that the project required more time than the seven weeks allotted and would have preferred to forgo the in-class, traditional education component of the course, and focus wholly on the applied, practical portion.

\section{Faculty commitment}

The course required significant advanced planning by instructors. Significant effort was required both pre- and post-calendar periods for the course, including setting up the activities and establishing partnerships. The instructors split their attention between the two group projects. Some students expressed that ambiguity and uncertainty as the projects developed and the perception of excessive reliance on the students to develop the projects should instead have been addressed by 
additional commitment from the instructors. However, project fluidity was exploited as a means of delivering a core competency of educating students about the nature of local policy and sustainability processes where change in direction on the part of staff is required in response to changes in perceptions about the probable efficacy of various work directions. The projects also required significant time commitment from service-learning partners. At the beginning of the semester partners met with students in class, to provide an informational foundation of their organization to establish familiarity with students.

\section{Research Question 2}

Our second research question exploring how course design and execution contribute to students acquiring core competencies in sustainability education was assessed across two course design principles: explicit connections between the service activity and learning objectives and perceptible impact of the service activity.

According to the baseline survey, this was the first time a majority of students had taken a service-learning course, only two students reported having taken a service-learning course in the past, and many exhibited limited understandings of service-learning. Understandings of servicelearning ranged from less accurate responses like "learning at your own pace" to more obvious responses like "learning through serving" and "similar to on the job training." The lack of servicelearning course experience (for students and instructors) appeared to have led to reduced perceptions of overall course clarity. Several students commented on the end of term course evaluation that more clarity in the service-learning project would have improved the course. This perceived lack of clarity may have also resulted in lower scores for this course, when compared to departmental mean scores for all courses on two clarity-related measures, on a scale from 1-

strongly disagree to 5- strongly agree: "content and materials were useful and organized" (3.9 course mean versus 4.6 departmental mean); and "teaching was clear, understanding and engaging" 
(3.9 course mean versus 4.6 departmental mean). It should be noted however, that no other servicelearning courses were taught in the department for more accurate comparisons across these measures.

Instructors must acknowledge that the intellectual and cognitive development position of different students in a multi-level course demand special attention to individual student abilities for critical and creative thinking, such as Perry's Scheme (Perry 1970; 1981). For instance, as a result of the diversity in student academic levels, the sophistication and understanding of sustainability that each student brought to the class differed greatly. It was clear from the baseline survey that the first 7-week section of the course, designed to bridge sustainability knowledge gaps and provide a common language through which students would understand sustainability and communicate for executing the service-learning projects, was highly necessary. Understandings of sustainability ranged from blank and "unknown" responses to simple notions like "continuity" to more holistic understandings like "balancing social, environment, and economic costs and benefits in order to establish and maintain symbiotic human systems that thrive by understanding and adhering to basic laws of nature." There was however, a smaller gap, than observed for clarity-related measures, between the course and departmental means for "acquired knowledge and skills that the course promoted" ( 4.2 course mean versus 4.6 departmental mean). It was also clear from student journals that understandings of the concept of sustainability and of the processes and hurdles required to implement sustainability-oriented plans and policies and subsequently evaluate the implementation of those plans and policies continued to evolve as students matriculated from the in-class section of the course through the service-learning section of the course.

\section{Perceptible impact of the service activity}

With both service-learning partners we agreed that the goal would be to produce materials that would be useful to their on-going work. Based on feedback from our service-learning partners, 
both projects provided significant assistance to their organizations that they might not have otherwise had. Throughout the course, we emphasized to students the importance of preparing a high-quality product for their project partners in order to maximize the service element of the course. At the same time, we emphasized to the partners that these were students who were learning about sustainability within the context of their organization's work and we could not guarantee a professional quality product. Additionally, the projects inspired students to participate in other civic engagement activities with some students noting that they were now participating in sustainability-related activities in their neighborhoods and on campus.

\section{Discussion}

To date, there is a dearth of critical research examining pedagogical practices beneficial for teaching all three E's of sustainability across professional higher education curricula. Overall, this course tilts toward a successful effort in designing and executing service-learning in a professional sustainability course, particularly the inclusion of the often-underrepresented dimension of social equity with projects focused on disadvantaged urban communities and food policy in rural communities. In regard to service-learning as a vehicle for delivering professional sustainability education, this course introduced students to a central issue for governments, nonprofits and businesses, provided them with a real-world glimpse of the environments within which they may work, gave them experience in generating a work product that may have significant public exposure and meaningfulness for social equity, and underscored the need for and challenges of collaborative work in a diverse team.

The integration of reflection activities for students is critical to facilitating sustainability learning. Based on student journal reflections, many if not all gained a greater understanding of the nature of sustainability and its environmental, economic, and social equity implications. For a subset of students there seemed to be growing sensitivity to how these implications manifest in policies and practices formulated by governments, nonprofits, and businesses. For another subset though, 
there remained a sense that the first 7-weeks of the course, was much less interesting and was perceived to be of minor value in comparison to the service-learning activity. Although personal engagement with service-learning partners varied between the two groups, and even within each group, the level of project engagement appeared to be an artifact of overall individual academic engagement, when observed project behavior was compared with individual performance on other course assignments.

Those interested in including a service-learning component in their sustainability course should take special care to consider project location/site and expected time and travel demands for students, instructors, and partners to meaningfully participate, including time outside of normal classroom or working hours. We learned that service-learning course design and execution are iterative processes requiring refinement over time, and ensuring mutual benefit that enhances sustainability efforts of service-learning partners as compensation for their time commitment is imperative to an enduring relationship.

Although additional service-learning courses have not been added to the department's curriculum, the university has committed to service-learning and its center for service-learning launched in 2015, and has maintained, a campus-wide mini-grants competition for undergraduate service-learning courses.

\section{References}

And, James Eflin, and Amy L. Sheaffer. "Service-learning in watershed-based initiatives: Keys to education for sustainability in geography?." Journal of Geography 105, no. 1 (2006): 33-44.

Boyte, Harry, and Elizabeth Hollander. "Wingspread Declaration on Renewing the Civic Mission of the American Research University [The Wingspread Conference](Racine, WI, December 11-13, 1998 and July 19-21, 1999)." (1999). 
Bringle, Robert G., Mindy A. Phillips, and Michael Hudson. The measure of service learning: Research scales to assess student experiences. Washington, DC: American Psychological Association, 2004.

Brundiers, Katja, Arnim Wiek, and Charles L. Redman. "Real-world learning opportunities in sustainability: from classroom into the real world." International Journal of Sustainability in Higher Education 11, no. 4 (2010): 308-324.

Budd, William, Nicholas Lovrich Jr, John C. Pierce, and Barbara Chamberlain. "Cultural sources of variations in US urban sustainability attributes." Cities 25, no. 5 (2008): 257-267.

Burns, Heather. "Teaching for transformation:(Re) Designing sustainability courses based on ecological principles." Journal of Sustainability Education (2011).

Dyllick, Thomas, and Kai Hockerts. "Beyond the business case for corporate sustainability." Business strategy and the environment 11, no. 2 (2002): 130-141.

Fiorino, Daniel J. "Sustainability as a conceptual focus for public administration." Public Administration Review 70 (2010): s78-s88.

Furco, Andrew. "Service-learning: A balanced approach to experiential education." (1996).

Howard, Jeffrey. Praxis I. A Faculty Casebook on Community Service Learning. OCSL Press, University of Michigan, Office of Community Service Learning, 2205 Michigan Union, Ann Arbor, MI 48109, 1993.

Imperial, Mark T., James L. Perry, and Michael C. Katula. "Incorporating service learning into public affairs programs: Lessons from the literature." Journal of Public Affairs Education 13, no. 2 (2007): 243-264. 
Jones, Angela Lewellyn, Beth Warner, and Pamela M. Kiser. "Service-learning \& social entrepreneurship: Finding the common ground." Partnerships: A Journal of Service Learning \& Civic Engagement 1, no. 2 (2010): 1-15.

Keen, Cheryl, and Elizabeth Baldwin. "Students promoting economic development and environmental sustainability: An analysis of the impact of involvement in a community-based research and service-learning program." International Journal of Sustainability in Higher Education 5, no. 4 (2004): 384-394.

King, Frederick B., and Diana LaRocco. "E-journaling: A strategy to support student reflection and understanding." Current Issues in Education 9 (2006).

Martin, A. "Professional Education shares Common Ground with Liberal Education", Teaching Matters, 14, no. 1 (2010): 1 .

Moore, Janet. "Seven recommendations for creating sustainability education at the university level: A guide for change agents." International Journal of Sustainability in Higher Education 6, no. 4 (2005): 326-339.

Opp, Susan M., and Kyle L. Saunders. "Pillar talk: local sustainability initiatives and policies in the United States-finding evidence of the "three E's": economic development, environmental protection, and social equity." Urban Affairs Review 49, no. 5 (2013): 678-717.

Ostrander, Susan A. "Democracy, civic participation, and the university: A comparative study of civic engagement on five campuses." Nonprofit and voluntary sector quarterly 33, no. 1 (2004): 74-93.

Perry, William. "Forms of intellectual and ethical growth in the college years." New York: Holt, Rinehart, and Winston (1970). 
Perry, W. G. "Cognitive and ethical growth: the making of meaning. IN CHICKERING, AW (Ed.) The Modern American College: Responding to the New Realities of Diverse Students and a Changing Society." (1981).

Pierce, John, Nicholas Lovrich, Bonnie Johnson, Tony Reames, and William Budd. "Social capital and longitudinal change in sustainability plans and policies: US cities from 2000 to 2010." Sustainability 6, no. 1 (2013): 136-157.

Portney, Kent E. Taking sustainable cities seriously: Economic development, the environment, and quality of life in American cities. MIT Press, 2013.

Reid, Randall. “ICMA Embraces Sustainability.” CitiesGoGreen.com. November 2008.

http://www.nxtbook.com/nxtbooks/verde/citiesgogreen_200811/index.php?startid=16.

Saha, Devashree. "Factors influencing local government sustainability efforts." State and Local Government Review 41, no. 1 (2009): 39-48.

Sipos, Yona, Bryce Battisti, and Kurt Grimm. "Achieving transformative sustainability learning: engaging head, hands and heart." International Journal of Sustainability in Higher Education 9, no. 1 (2008): 68-86.

Sigmon, Robert. "Service-learning: Three principles." Synergist 8, no. 1 (1979): 9-11.

Stanton, Timothy K., Dwight E. Giles Jr, and Nadinne I. Cruz. Service-Learning: A Movement's Pioneers Reflect on Its Origins, Practice, and Future. Jossey-Bass Higher and Adult Education Series. JosseyBass Inc., Publishers, 350 Sansome St., San Francisco, CA 94104, 1999. 